\title{
The Way to Cultivate Intercultural Communicative Competence in Japanese Teaching
}

\author{
Chunhua Piao \\ Dalian Neusoft University of Information \\ Liaoning, China 116023
}

\begin{abstract}
Foreign language education has two goals, one is linguistic and literary goal, and the other is social humanistic goal. Social humanistic education refers to intercultural education, aimed at cultivating cross-cultural awareness, knowledge, and ability to live in harmony with people from different cultural backgrounds, then effectively communicate and cooperate with each other. In the era of global economic integration, it is imminent to cultivate Japanese talents with intercultural communicative competence. Traditional way of teaching Japanese focuses on cultivating students'language application ability, while neglects the cultivation of intercultural communicative competence. This study has analyzed the causes of intercultural communication barriers and offers effective ways to cultivate intercultural communicative competence in Japanese language teaching.
\end{abstract}

Keywords-intercultural communicative competence; cultural differences; intercultural communication barriers

\section{INTRODUCTION}

In 2010, the Outline of the National Medium-and Longterm Educational Reform and Development Plan (2010-2020) clearly stipulated that "To improve the internationalization of education in China, multi-level and wide-ranging education and cooperation should be carried out." "International talents who are able to participate in international affairs and international competition with international perspective and know its rules should be cultivated." The goal of foreign language teaching should be the cultivation of learners' intercultural communication ability instead of the cultivation of language application ability. Intercultural communicative competence refers to the ability to communicate with people with different languages and cultural backgrounds. Intercultural communicative competence is neither equivalent to linguistic competence nor communicative competence. Traditional Japanese teaching focuses on cultivating students' language application ability and neglects the cultivation of intercultural communicative competence, which leads students to encounter frustration in intercultural communication and bring bad influence to both themselves and those they are communicating with. Of course, the most basic condition for communicating with foreigners is to master the language application ability, but culture is an important factor to improve intercultural communication ability.

\section{CUltural DifFERENCES CAUSE INTERCUlTURAL BARRIERS}

\section{A. Sino-Japanese Cultural Differences}

Although Japanese language system comes from Chinese, there is huge difference between Chinese and Japanese culture. So even if the students can speak fluent Japanese, it is inevitable that there are barriers and misunderstanding in the communication with Japanese. The primary task of Japanese language teaching is to cultivate students' language application ability. In this way, we should pay attention to cultivating students' intercultural communicative competence

Grasping the language, but lacking in the understanding of Japanese culture, Japanese habits and the Japanese values, will result in a lot of unnecessary trouble and misunderstanding. For example, Japanese are very strict about time and they are punctual. Although time concept of Chinese people is constantly strengthened, being late for a few minutes is acceptable. However, in the Japanese culture, not being strict with time is considered to be uncreditable. Especially in business activities, it is difficult to establish cooperating relationship with each other. There are many differences like this in Sino-Japanese culture. Therefore, not only Japanese language knowledge should be teaching in colleges and universities, but also values and linguistic habits of Japanese people should be paid attention to. In this way, intercultural communicative ability of students should be raised.

\section{B. Definition of Intercultural Communicative Competence}

The intercultural communicative competence, widely recognized by many scholars in this field, refers to the ability to communicate effectively and appropriately with people of different cultural backgrounds. Intercultural communicative ability include cognitive, emotional, behavioral these three ability.

\section{The Necessity to Cultivate Intercultural Communicative Competence}

Fan Weiwei (1999) pointed out that foreign language teaching should be turned to foreign language education, which means that, it is not only the cultivation of foreign language quality, but also the cultural quality and then improving the overall quality, so that students can use foreign language for intercultural communication after graduation. We 
can see the importance of cultivating students' intercultural communicative competence. BiJiwan (2005) pointed out that the main task of second language teaching is to cultivate students' cross-cultural communication ability. That is to say, it is comprehensive ability made up of linguistic communicative ability, nonverbal communicative competence, language rules, conversion capacity of communication rules and cultural adaptability.

In the 10th World Japanese Language Education Research Conference, Xiu Gang put forward the theme of "Japanese Language Teaching for Intercultural Communication”, and believed that it is very important to deepen communication and understanding of people from these two countries through Japanese language teaching for the purpose of intercultural communication. Therefore, Xiu Gang proposed a "three-step" plan, which is as following: "To increase the cultural understanding of both sides, to cultivate students' intercultural communication skills, we have to focus on the following points. The first is to understand Japan, the second is to be familiar with our own culture, and last, we must have a strong ability to communicate, and persuade each other by the way that is acceptable by those we are communicating with." So we can see the importance of intercultural communication in Japanese teaching. Language teaching is not only a way of imparting language knowledge, but also the way to inserting culture of target language. Traditional way of Japanese language teaching is mainly based on the teaching of language knowledge and the cultivation of language skills, instead of the introduction of Japanese culture and the cultivation of intercultural communication skills, which makes the students have difficulty in communicating with Japanese people, thus the conversation cannot go smoothly.

$\mathrm{Hu}$ Wenzhong (2005) pointed out that all the effort we have done is to cultivating students' intercultural communication ability.

\section{The WAY TO CUlTivate INTERCULTURAL COMMUNICATIVE COMPETENCE}

\section{A. Improve Intercultural Communicative Competence by Different Lectures}

The main reasons for the emergence of cross-cultural barriers are as follows: the first lack of understanding of Japanese culture; the second did not grasp the Japanese language expression; the third does not understand the Japanese way of thinking.

Fundamental Course of Japanese, Japanese Listening and Japanese Conversation are the core courses of Japanese majors. In addition to the basic knowledge of Japanese language, Japanese culture should be introduced in the lectures to help students understand Japanese culture, cultivate students' cultural sensitivity and cross-cultural awareness. Japanese Viewing, Listening and Speaking is a very good course for students to learn Japanese culture. Listening is inseparable from multimedia. Teachers can find videos about Japanese culture, both to help students practice listening, and to allow students to intuitively know Japanese culture. In fact, watching animation is a very good way to understand Japanese society. There will be a lot of Japanese social and cultural related scenes in animation. For example, from the animation, we will see Japanese streets and houses, and also know how Japanese strictly comply with traffic lights, and their dressing habits. These are all the parts that cannot be understood through language. In addition, by watching the workplacerelated Japanese drama, students can understand Japan's vertical society, and in the company, employees strictly abide by leader-member relation. A drama called Don't Be Married can help students understand the current Japanese young people's view of marriage, you can also know that now $20 \%$ of the Japanese don't want to be married. When you know these, it is not difficult to understand why the Japanese society is now suffering from sub-replacement fertility. If students can understand Japanese social knowledge, when communicating with Japanese, they will not be embarrassed because of no topic, thereby through the communication they can know more about each other. Students can learn knowledge that doesn't have in books and also Japanese culture-related things through the videos. In this way, it is the most effective way to cultivating intercultural communicative ability by learning Japanese culture through videos. There are courses like Japanese Profile, Japanese Literature, and Business Etiquette, which can also help students learn about Japanese culture and improve cross-cultural communication skills. Japan Profile is the best book to learn about Japan. Through this course, students can have a wide range of cultural knowledge, such as Japanese geography, economy, politics, transportation, and environment. The current problem is that students do not attach importance to this course. In this circumstance, teachers should guide students to know the importance of learning culture and cultivate students' cultural sensitivity through a variety of teaching methods.

Japanese Literature is also a course that cannot be ignored. For Japanese learners, literary knowledge should be grasped as a common sense. Just as there is no Chinese that do not know the four major classical novels, it is very necessary for Japanese learners to master and understand Japanese literature. We can communicate with Japanese smoothly with Japanese literary knowledge. A person's ability to speak Japanese is always proportional to his cultural knowledge. So that there will be less misunderstanding and barriers in intercultural communication.

Business Etiquette course is offered as an elective course in some Japanese language colleges. But the author believes that Business Etiquette course should be a compulsory course. Most of Japanese learners are going to work in Japanese companies or Chinese companies that have business relationship with Japan. Interview is a must for those who want to enter Japanese company. Although the interview will be finished in a few minutes, lots of business etiquette details can be seen. We dare to say that many Japanese interviewers hire new employees by their behavior. In Japan, interview etiquette is the most basic protocol that one must have. If one cannot do this, he is not suitable to be a social man. One can imagine how the Japanese attach importance to etiquette. By understanding these Japanese values and their way of thinking, students will pay great attention to learn Business Etiquette course. Teachers should guide students correctly to let them 
know the importance of culture in language and work. All in all, it is not correct to learn language without culture. Without culture, language cannot play its function of communication.

\section{B. Improve Intercultural Communicative Competence by Communicating with Foreign Teachers}

Most foreign teachers are teaching Japanese conversation in colleges and universities. Foreign teachers can help students to improve their pronunciation and also improve their oral expression. Foreign teachers can also teach students their local way of expression to make students know Japanese way of thinking. Appropriate expression can be taught through this way. In addition, communicating with foreign teachers in the classroom is also a good way to understand Japanese way of speaking and working. For example, foreign teachers rarely criticize students as directly as Chinese teachers do, and students rarely see foreign teachers criticize students in class. This is related to the way Japanese do and think. Japanese prefer to euphemistically express to avoid direct damage to each other. What's more, in order to have conflict with other people, they are perusing harmony.

\section{Improve Intercultural Communicative Competence through Short-term Study in Japan}

If there is chance for students to go abroad as exchange students or for short-term study during their undergraduate study, they will have great improvement in intercultural competence. Some colleges and universities have established overseas language practice base to send students study there, thus their ability can be improved. Colleges and universities have responsibility to promote the exchange of Japanese and Chinese universities, to provide more opportunities for students to experience Japanese culture. With the reduction of Japanese university students, Japanese universities are also expanding their exchange programs with foreign universities, so more students will be able to experience Japanese culture in the future.

In addition to these projects, some colleges and universities are actively developing projects like $2+2$ and $3+1$, these can also develop students' intercultural communication skills effectively. The facts have proved that students who have participated in these projects are popular in enterprises, and they can find good jobs as well. For example, one of the world's top 500 IT companies hires students who came back from Japan mostly in their call center. Because working in call center, expressive ability and skills are the main focuses. By study in Japan, students can have good expressive ability and know Japanese culture very well. These are the basic condition for people who work in call center. So the importance of intercultural competence in employment should be clearly noticed.

\section{IMPROVE INTERCULTURAL COMMUNICATIVE COMPETENCE BY GRASPING JAPANESE BUSINESS CULTURE COMMON SENSE}

Many Japanese learners will enter Japanese companies or do business with Japan after graduation. For such learners, improving business cultural knowledge is the key to enhance intercultural communication skills. Avoiding intercultural barriers and conflicts is the guarantee for the smooth conduct of international business activities. In international business activities, business negotiation is an important part for the occurring of cultural conflict. In the process of intercultural negotiation, goal of both sides is being clear, convincible and to sign the contract in the end. Business communication is an important way in doing trade, during the communication, both sides should respect each other's customs, have a clear view of time and holiday arrangements, understand taboo and gift custom, avoid cultural differences and misunderstanding and conflict. Therefore, during intercultural communication, personal business cultural literacy should be raised, we have to recognize each other's culture, to comply with each other's business etiquette.

\section{CONCLUSION}

At present, many Japanese educators agree that the purpose of Japanese education is to cultivate intercultural communication competence. But in the implementation of education, there will be many problems. Some factors come from the educators. The educators themselves are also cultivated by traditional Japanese education, so they are lacking in intercultural communication ability. So the priority is to improve the teacher's intercultural communication competence. In addition, it is obvious that it is impossible for all Japanese students to have high intercultural communicative competence in the end. Intercultural communication ability can not only rely on the lectures. Besides the lectures, students can also improve this ability by study abroad. Therefore, it is a long-term process for cultivating intercultural communicative competence which can be improved communicating with foreigners.

\section{REFERENCES}

[1] $\mathrm{Hu}$ Wenzhong, Orientation of Intercultural Communicative Competence in Foreign Language Teaching, Foreign Language World, 2013.6

[2] Bi Jiwan, The Main Task of Second Language Teaching is to Cultivate Students' Intercultural Communicative Competence, Chinese foreign language2005.1

[3] Fan Weiwei, Foreign Language Education and Intercultural Communicative Competence training, Higher Education Research, 1999.2

[4] Xu Lisheng, Study on Intercultural Communicative Competence, Foreign Languages and Their Teaching, 2000.7

[5] Chen Xin, Explore the Curriculum for Cultivating International Foreign Language Personnel from the Perspective of Intercultural Communicative Competence, Foreign Language World 2012.5 